\title{
Leidt flexibilisering van werktijden en -plaats tot gezondheidsrisico's?
}

\author{
Maroesjka Versantvoort \& Karolus Kraan*
}

\begin{abstract}
Werknemers in de flexibele schil blijken geconfronteerd te worden met meer gezondheidsrisico's dan werknemers in vaste dienst. De vraag die in dit artikel centraal staat, is of flexibiliteit van werktijden en -plaats eveneens zorgt voor meer gezondheidsproblemen. De paneldata-analyses op basis van de Nationale Enquête Arbeidsomstandigheden laten evenwel zien dat plaats- en tijdonafhankelijk werk juist vermindering van gezondheidsrisico's betekent. Het ziekteverzuimpercentage van telewerkers is 0,4 tot 0,5 procentpunt lager dan dat van vergelijkbare werknemers die niet telewerken. Zij ervaren meer autonomie dan werknemers die niet thuis- of telewerken. Ook hebben ze een betere relatie met hun collega's en leidinggevenden. Daar staat tegenover dat thuis- en telewerkers vaker problemen ervaren in de afstemming van werk en zorg. Ze hebben vaker het gevoel ofwel de familie tekort te doen ofwel het werk.
\end{abstract}

\section{Inleiding}

De Nederlandse arbeidsmarkt wordt steeds flexibeler. Het aandeel werknemers met een flexibele arbeidsrelatie is toegenomen van 12 procent in 2001 tot 16 procent van de werkzame beroepsbevolking in 2012. Het aandeel zelfstandigen zonder personeel is in die periode toegenomen van 7 naar 10 procent van de werkzame beroepsbevolking (Van Gaalen et al., 2013). Als we flexibiliteit bezien in het perspectief van het aandeel werknemers met een flexibel contract inclusief zelfstandigen - op de totale werkzame bevolking, dan behoort Nederland tot een van de meest flexibele arbeidsmarkten van de Europese Unie (na Polen, Spanje, Italië, Portugal en Griekenland). Als het alleen gaat om flexibele contracten, exclusief zelfstandigen, staat Nederland zelfs vierde (De Beer, 2011, p. 92). Deze ontwikkeling kent evenwel niet louter winnaars.

De Beert (2011) schetst het risico op een tweedeling tussen insiders - werknemers met een vaste baan - en outsiders - flexwerkers en werklozen. Recent onderzoek van TNO en het CBS (Van Gaalen et al., 2013) laat zien dat werknemers met een flexibele arbeidsrelatie vaker uitstromen naar werkloosheid of inactiviteit dan werknemers met een vaste arbeidsrelatie. Werknemers met een flexibele arbeidsrelatie blijken niet alleen te kampen met minder baanzekerheid, ze hebben ook vaker te maken met een hoge werkdruk en weinig autonomie op het werk (Van Gaalen, et al., 2013). Hierdoor worden zij met meer gezondheidsri-

* Maroesjka Versantvoort is werkzaam bij het Sociaal en Cultureel Planbureau, e-mailadres: m.versantvoort@scp.nl. Karolus Kraan is werkzaam bij TNO. 
sico's geconfronteerd en hebben zij meer problemen met de inzetbaarheid dan werknemers met een vaste arbeidsrelatie.

De flexibiliseringstrend van de afgelopen jaren betreft niet alleen het arbeidscontract. Ook de organisatie van arbeid is aan verandering onderhevig. Voor steeds meer typen arbeid lijkt in een kennisintensieve samenleving de plaats waar die arbeid wordt verricht, minder relevant, evenals het tijdstip waarop dat gebeurt. Zo is van 2007 tot 2010 het aandeel telewerkers toegenomen van 12 tot 15 procent van alle werknemers in Nederland (Koppes et al., 2011a). Sinds 2000 is sprake van een toename van ongeveer één procentpunt per jaar (Hooftman et al., 2011). Onduidelijk is of deze vorm van flexibilisering - het loslaten van vaste tijden en plaatsen van arbeid - dezelfde risico's kent als de flexibilisering van het contract tussen werknemer en werkgever.

In maatschappelijke en wetenschappelijke discussies wordt met name ingezoomd op de mogelijke meerwaarde van tijd- en plaatsonafhankelijk werken. In de eerste plaats biedt thuis- en telewerk werknemers mogelijkheden om de afstemming van arbeid en zorg te optimaliseren. Zo kunnen bij thuis- en telewerk arbeidstijden gemakkelijker rondom zorgverplichtingen worden gepland en kan met thuis- en telewerk beter worden ingespeeld op crises in de gezinssfeer (zie Gajendran \& Harrison, 2007). Ook biedt thuis- en telewerk mogelijkheden de fileproblematiek te verlichten (Baruch, 2001). Wanneer een werknemer vanuit huis werkt, hoeft deze immers niet meer de weg op om te pendelen naar het werk. Verder biedt thuis- en telewerk kansen om de arbeidsproductiviteit te bevorderen en ziekteverzuim te verminderen. Deze kansen worden onder meer gecreëerd door vergroting van de autonomie van de werknemer (Standen et al., 1999) en vermindering van (reis- en kantoor)stress (Montreuil \& Lippel, 2003; Baruch, 2001).

De kansen die thuis- en telewerk biedt om de arbeidsparticipatie en -productiviteit te verhogen, staan evenwel niet op zichzelf. Thuis- en telewerk gaat mogelijk ook samen met gezondheidsrisico's die de kansen op een toenemende arbeidsproductiviteit ondermijnen. Zo kan thuis- en telewerk leiden tot gevoelens van isolatie en vereenzaming, van nooit meer klaar zijn met werken, schuldgevoelens of werkvervreemding (Mann \& Holdsworth, 2003; Gajendran \& Harrison, 2007). Ook zou een intensieve toepassing van thuis- en telewerk druk kunnen leggen op de relatie tussen werknemer en leidinggevende en die tussen werknemers onderling (McClosky \& Igbaria, 2003).

Dit artikel tracht een bijdrage te leveren aan deze discussie en zoomt in op de mogelijke gezondheidsrisico's die gepaard gaan met flexibilisering van werktijden en -plaats. Daarbij wordt ook aandacht besteed aan de gevolgen voor autonomie, de relaties tussen werknemers, en de afstemming tussen werk en zorg; factoren die mogelijk ten grondslag liggen aan deze risico's. ${ }^{1}$

De volgende onderzoeksvraag staat centraal:

In hoeverre leidt thuis- en telewerk tot grotere gezondheidsrisico's?

Subvragen die daarbij behandeld worden, zijn:

- Ervaren thuis- en telewerkers meer of minder autonomie dan werknemers die niet thuis- of telewerken? 
- Hebben thuis- en telewerkers meer of minder problemen in hun relatie met collega's en leidinggevenden dan werknemers die niet thuis- of telewerken?

- Ervaren thuis- en telewerkers een betere of slechtere afstemming tussen werk en zorg dan werknemers die niet thuis- of telewerken?

Om inzicht te krijgen in de gezondheidsrisico's richten we ons op de ontwikkelingen in het ziekteverzuim van werknemers. Hoewel deze grootheden niet gelijk zijn, zullen grotere gezondheidsrisico's veelal tot uitdrukking komen in een hoger ziekteverzuim. We pogen dan de consequenties van thuis- en telewerk voor ziekteverzuim van werknemers in Nederland inzichtelijk te maken. Om bovenstaande vragen te kunnen beantwoorden worden paneldata-analyses verricht van data uit de Nationale Enquête Arbeidsomstandigheden (Koppes et al., 2011b). Deze enquête is gestart in 2003 en wordt sinds 2005 jaarlijks gehouden.

Hoewel thuiswerk en telewerk vaak als inwisselbare begrippen gebruikt worden, is de betekenis niet identiek. Waar thuiswerk verwijst naar werk dat mensen (gedeeltelijk) vanuit huis verrichten, gaat het bij telewerk om een alternatieve werkvorm waarbij een werknemer op een andere locatie taken uitvoert dan de centrale werklocatie en gebruikmaakt van informatie- en communicatietechnologie (ICT) om te communiceren met anderen binnen en buiten de organisatie (Gajendran \& Harrison, 2007; Baruch, 2001; Bailey \& Kurland, 2002). De alternatieve locatie kan zowel de thuisomgeving zijn als een andere omgeving. Ook kan de intensiteit verschillen - van parttime, waarbij een deel van de week gekozen wordt voor een alternatieve werklocatie, tot fulltime, waarbij bijvoorbeeld hoofdzakelijk vanuit huis gewerkt wordt. Terwijl in de definitie van telewerk de ICT-eis geldt, is deze bij thuiswerk niet aan de orde. Bij de analyses in het vervolg van dit artikel wordt zo veel mogelijk rekening gehouden met het onderscheid tussen thuis- en telewerk.

\section{Analytisch kader}

Welke factoren spelen nu een rol wanneer we de relatie tussen thuis- en telewerk en ziekteverzuim in beschouwing nemen? De afgelopen jaren zijn verschillende studies verricht naar de consequenties van thuis- en telewerk, waarin verschillende accenten gelegd zijn. Gajendran en Harrison (2007) hebben ter beantwoording van bovenstaande vraag een meta-analyse uitgevoerd van beschikbaar onderzoek. Daarin hebben zij verschillende perspectieven geclusterd in een beperkt aantal factoren. Figuur 1 toont de redeneerlijn.

Thuis- en telewerk beïnvloedt zowel direct als indirect individuele werkresultaten en arbeidsproductiviteit, en ziekteverzuim in het bijzonder. Het geeft werknemers de keuze om op een andere locatie het werk uit te voeren dan de centrale locatie. Ook leidt het tot lagere werkgerelateerde kosten, doordat besparingen gerealiseerd kunnen worden op bijvoorbeeld vervoer, reistijd, lunch of werkkleding. Het bieden van de mogelijkheid tot thuis- en telewerk symboliseert de bereidheid van de werkgever de werkomgeving aan te passen aan de behoeften van de werknemers. Hierdoor kan de baan afgestemd worden op de wensen van 


\section{Figuur 1 Analytisch kader relatie thuis- en telewerk en ziekteverzuim}

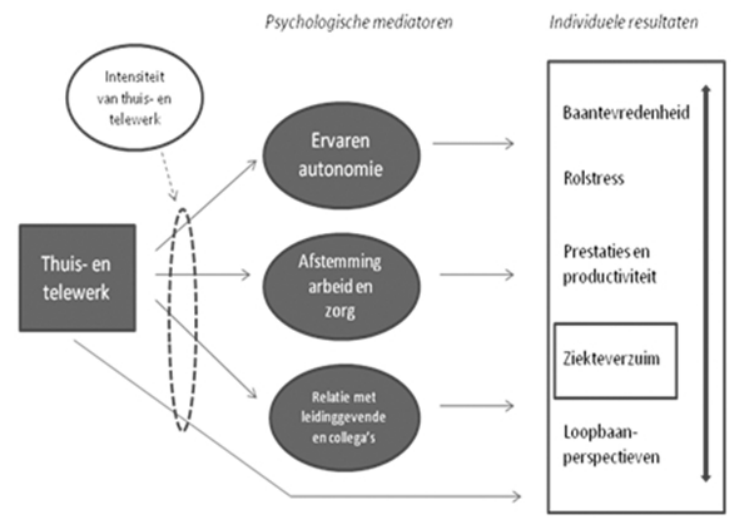

Zie (SCP), op basis van Gajendran en Harrison (2007)

de werknemer, zodat de baantevredenheid kan toenemen en de geneigdheid tot ziekmelden afnemen (Baltes et al., 1999). Toegenomen arbeidsproductiviteit wordt daarnaast als mogelijk positief gevolg van thuis- en telewerk beschouwd (zie bijvoorbeeld McClosky \& Igbaria, 2003), doordat minder werkonderbrekingen plaatsvinden vanwege onder andere 'social talk' en minder tijd verloren gaat aan reizen van en naar het werk. Een derde verwacht gevolg is gelegen in verminderde stress die samenhangt met de voorbereiding op en het reizen naar het werk. Ook de verplichting elke werkdag op een bepaald tijdstip aanwezig te zijn en dus de mogelijkheid verlaat te zijn, leidt tot stress omdat 'te-laat-zijn' negatief samenhangt met reputatie. Thuis- en telewerk zou dan stressverlagend kunnen zijn. Daar staat tegenover dat onduidelijkheid over de rol die werknemers hebben wanneer zij thuis zijn (werkgever, vader, opdrachtgever), weer stressverhogend kan zijn. Een vierde consequentie van toepassing van thuis- en telewerk op de individuele prestaties betreft mogelijk verminderde loopbaankansen. Door telewerk vermindert de zichtbaarheid evenals de mogelijkheid in face-to-face gesprekken de vaardigheden en kennis te tonen. Ook kan het thuis- of telewerken door sommigen opgepakt worden als verminderde toewijding aan het werk. Hierdoor schatten werknemers die regelmatig telewerken, hun loopbaankansen mogelijk lager in dan zij die nooit telewerken. Verminderde gepercipieerde doorgroeimogelijkheden en verhoogde rolstress zouden mogelijk positief kunnen samenhangen met ziekteverzuim, toegenomen productiviteit negatief (Gajendran \& Harrison, 2007). We spreken bij de individuele resultaten overigens over samenhang en niet over causaliteit. De richting van de causaliteit is voor de meeste van deze indicatoren immers meerledig.

Naast deze directe vormen van impact onderscheidt figuur 1 ook enkele indirecte vormen van invloed van thuis- en telewerk op ziekteverzuim. Deze indirecte invloed verloopt via drie onderscheiden psychologische 'mediatoren': ervaren autonomie, afstemmingsmogelijkheden arbeid en zorg, en relaties met leidinggevenden en collega's. De ervaren autonomie heeft betrekking op de inschattin- 
gen van de werknemer van de mate waarin deze controle heeft over hoe en wanneer de werkzaamheden te verrichten (Spector, 1986). Thuis- en telewerk zou positief kunnen bijdragen aan de ervaren autonomie, doordat deze werkvorm werknemers keuzevrijheid verschaft als het gaat om locatie, tijdstip en wijze van uitvoeren van werkzaamheden. Het type werk lijkt evenwel doorslaggevend. Standen et al. (1999) stellen dat voor laag kennisintensief werk, zoals data-invoer, waarbij elektronische supervisie meer voor de hand ligt dan face-to-face supervisie, de organisatie rond telewerk juist leidt tot een gevoel van minder autonomie (Standen et al., 1999). Immers, controle via ICT is veelal minder flexibel dan directe supervisie door een leidinggevende. Daarnaast beïnvloedt thuis- en telewerk de afstemming tussen werk- en zorgtaken. Sommigen zien met name een negatieve invloed; door de ondoorzichtigheid van de grenzen tussen werk en privé die gepaard gaat met thuis- en telewerk, zullen eerder conflicten ontstaan in de afstemming van arbeid en zorg (Standen et al., 1999; Igbaria \& Guimaraes, 1999). Anderen zien daarentegen vooral kansen en wijzen op de mogelijkheden die thuis- en telewerk biedt om arbeid en zorg te integreren en daarmee rolconflicten te minimaliseren (Duxbury et al., 1998; Raghuran \& Wiesenfeld, 2004). Een derde mediator die beïnvloed wordt door het al dan niet toepassen van thuisen telewerk, is de relatie van de werknemer met de leidinggevende en collega's. Minder aanwezigheid (in frequentie en duur) en minder face-to-face contacten verzwakken de relaties met collega's en leidinggevende(n) (Golden, 2006), die vervolgens de individuele resultaten niet ten goede komen.

De te verwachten impact van deze mediatoren wijst op een thuis- en telewerkparadox van onverenigbare consequenties voor werknemers (zie Gajendran \& Harrison, 2007). Wanneer thuis- en telewerk zorgt voor een toename in de ervaren autonomie en een afname in belangenconflicten tussen arbeid en zorg, zou dit stress kunnen verlagen, en baantevredenheid en productiviteit kunnen laten toenemen. Wanneer thuis- en telewerk tegelijkertijd zorgt voor beschadigde verhoudingen op de werkvloer, zal dit geen positieve gevolgen hebben voor de individuele resultaten in het algemeen en de loopbaanperspectieven in het bijzonder. Mogelijk staan de eerste twee mediatoren op gespannen voet met de laatste, met als doorwerking ook een ambigue verwachting over de consequenties voor ziekteverzuim. De positieve effecten van de eerste twee mediatoren leiden mogelijkerwijs tot een afname van ziekteverzuim, de negatieve van de derde mediator tot een toename.

De laatste factor die wordt onderscheiden in figuur 1, betreft de intensiteit van thuis- en telewerk. De impact van bovengenoemde factoren wordt afhankelijk verondersteld van de intensiteit waarmee een werknemer gebruikmaakt van thuis- en telewerk. Naarmate de intensiteit hoger is, worden de bovengenoemde effecten groter verwacht. Daarbij kan een onderscheid worden gemaakt tussen hoog-intensieve telewerkers ofwel de 'home-centered' - zij die het merendeel van de werktijd besteden op een alternatieve locatie - en laag-intensieve telewerkers, de 'office-centered' - zij die het merendeel van de werktijd op kantoor doorbrengen. Uit onderzoek van Konradt et al. (2003) blijkt dat 'home-centered' en 'officecentered' telewerkers verschillen in motivatie om te telewerken. De 'home-cente- 
red' telewerkers zoeken met name balans in hun werk- en zorgtaken. De 'officecentered' telewerkers proberen vooral te ontkomen aan werkonderbrekingen.

Opgemerkt moet worden dat dit schema geen rekening houdt met verschillen in preferenties ten aanzien van (het belang van) werk. Het gaat uit van de gemiddelde thuis- of telewerker. De preferenties geven evenwel richting aan het belang dat gehecht wordt aan werk, en ze bepalen zodoende ook het perspectief waarin telewerk of thuiswerk plaatsvindt. Sommige mensen werken met name om financiële redenen, voor andere gaat het om sociale contacten of een zinvolle tijdsbesteding (Van Echtelt, 2010). Zo kan worden aangenomen dat voor werkenden die een groot belang hechten aan sociale contacten in het werk, de eventuele efficiëntiewinst uit thuis- of telewerk minder waarde heeft dan voor hen die het niet gaat om de sociale contacten, maar primair om de financiële opbrengsten. De impact van een betere afstemming van arbeid en zorg door thuiswerk op ziekteverzuim op persoonsniveau kan - door variatie in voorkeuren - daarom ook afwijken van de gemiddelde impact. Voor mensen die werken om de sociale contacten, zal het ziekteverzuim dempende effect wellicht kleiner zijn dan voor mensen die werken om financiële redenen.

Ook dient te worden opgemerkt dat een deel van het effect van thuis- en telewerk op ziekteverzuim verklaard kan worden door de situatie dat thuis- en telewerkers zich minder snel ziek melden, doordat zij 'al thuis zijn'. Daar staat echter tegenover dat thuiswerkende werknemers bij ziekte mogelijk eerder naar vermogen zullen doorwerken. Zo is het opstarten van de computer om e-mail te lezen voor sommige zieke werknemers wellicht nog wel te doen, maar is het reizen naar en van het werk mogelijk te vermoeiend. Zoals de grens tussen werk en privé bij thuiswerk vervaagt, zo vervaagt in die omstandigheid ook de grens tussen niet en wel (parttime) werkzaam kunnen zijn.

\section{Ontwikkeling thuis- en telewerk}

Voordat we in de volgende paragraaf gaan analyseren welke consequenties thuisdan wel telewerk heeft voor ziekteverzuim, zetten we in deze paragraaf enkele kerncijfers uiteen. Hoe vaak komt thuis- en telewerk nu voor in de Nederlandse samenleving? Zijn eventuele verschillen in ziekteverzuim tussen mensen die wel en mensen die niet thuis- of telewerken op het eerste gezicht opvallend?

Met behulp van gegevens afkomstig uit de Nationale Enquête Arbeidsomstandigheden (NEA) (Koppes et al., 2011a) zijn deze vragen te beantwoorden. De NEA wordt jaarlijks uitgevoerd door TNO en het CBS, met een landelijke representatieve respons van 23.000 werknemers. De NEA bevat twee vragen die zich specifiek richten op thuis- en telewerk. Over thuiswerk wordt gevraagd hoeveel van de normale arbeid gemiddeld in uren thuis verricht wordt (uitgezonderd overwerk). Deze variabele is omgezet naar drie zogenoemde dummy-variabelen: één die aangeeft dat geen sprake is van thuiswerk, één die aangeeft dat gemiddeld maximaal een vijfde (20 procent) van de normale arbeid thuis verricht wordt, en één die aangeeft dat gemiddeld meer dan 20 procent van de normale arbeid thuis verricht wordt. Over telewerk wordt in NEA gevraagd of de respondent telewerker is - dat 
Figuur 2 Ontwikkeling aandeel thuis- en telewerk

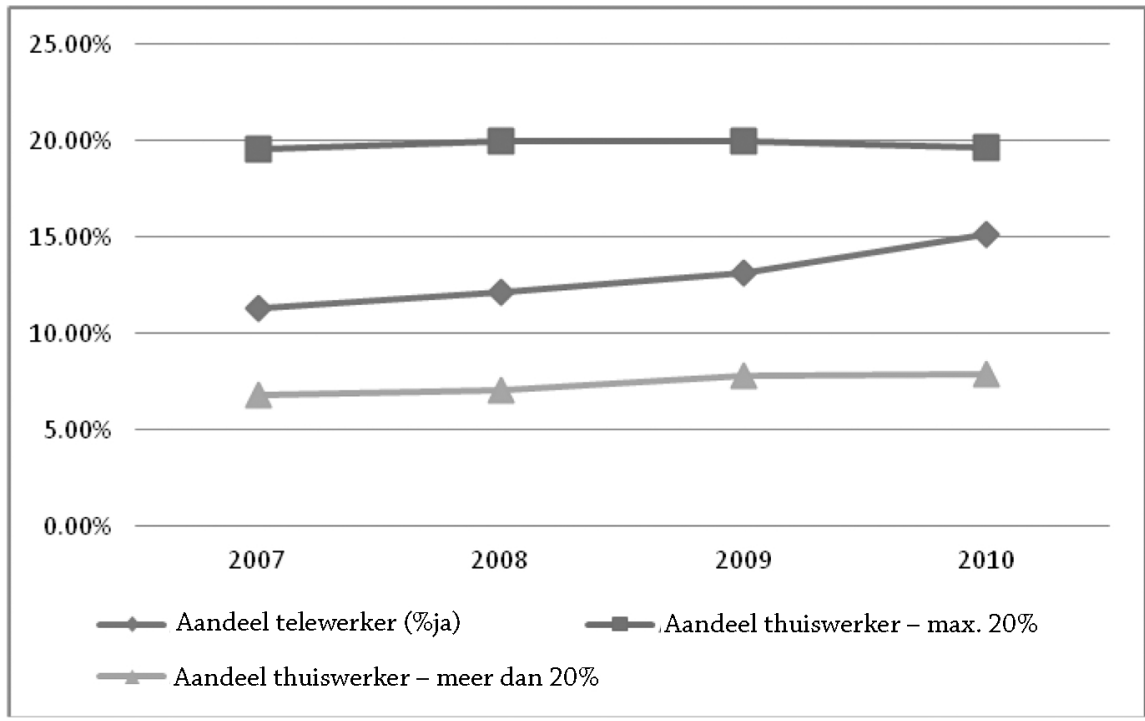

Bron: SCP (2012) op basis van NEA (2007-2010)

wil zeggen dat deze met behulp van een computer, thuis of elders, werk doet dat hij of zij ook bij de werkgever of de opdrachtgever uitvoert. Deze dichotome variabele is zonder aanpassingen opgenomen in de analyse als variabele voor telewerk. 15 procent van de Nederlanders geeft in 2010 aan telewerker te zijn (zie figuur 2). Het aandeel telewerk is sinds 2007 met 4 procentpunten gestegen. De toename van thuiswerk was minder sterk dan die van telewerk. Het aandeel werknemers dat meer dan 20 procent van de normale arbeidstijd thuis verricht, nam tussen 2007 en 2010 zeer licht toe (een procent) en het aandeel dat maximaal 20 procent van de arbeidstijd thuiswerkt, bleef vrijwel gelijk in die periode. In 2010 werkt 28 procent van de Nederlanders wel eens thuis; voor 20 procent is dat minder dan 20 procent van de normale arbeidstijd, voor 8 procent meer.

Vergelijken we deze groepen op hun gemiddelde ziekteverzuim, dan valt op dat telewerkers een significant lager gemiddeld ziekteverzuim van 1,1 procentpunt hebben dan niet-telewerkers (zie tabel 1). Vergelijken we de groepen thuiswerkers met niet-thuiswerkers, dan zien we dat juist de groep die een relatief klein deel (voor voltijders één dag in de week) van de normale arbeidstijd thuiswerkt, het laagste ziekteverzuim kent. Voor mensen die meer dan 20 procent van de normale arbeidstijd thuiswerken, is het ziekteverzuim niet lager dan dat voor mensen die niet thuiswerken. ${ }^{2}$ 
Tabel 1 Gemiddeld ziekteverzuimpercentage voor werknemers die al dan niet thuis- of telewerken

\begin{tabular}{lllll}
\hline Vergelijkingsgroep & $\begin{array}{l}\text { Gemiddeld verzuimpercentage } \\
\text { (deeltijdgecorrigeerd) }\end{array}$ & N & t \\
\hline Telewerker - nee & 4,3 & 76616 & \\
Telewerker - ja & 3,2 & 11519 & $9,91 * * *$ \\
Thuiswerker - nee & 4,3 & 56584 & \\
Thuiswerker - maximaal 20\% & 3,5 & 15466 & \\
Thuiswerker - meer dan 20\% & 4,1 & 5774 & $29,09 * * *$ \\
\hline
\end{tabular}

Bron: SCP (20I2) op basis van NEA (2007-20I0).

$* \mathrm{p}<, 05 ; * * \mathrm{p}<, 01$; *** $\mathrm{p}<, 001$

\section{Gezondheidsrisico's thuis- en telewerk}

De statistieken uit de vorige paragraaf doen veronderstellen dat thuis- en telewerk verlagende effecten hebben op ziekteverzuim. Deze houden evenwel geen rekening met verschillen in achtergrondkenmerken tussen werknemers. Analyses van Smulders et al. (2011), eveneens op basis van data uit de NEA, hebben laten zien dat thuis- en telewerk niet gelijk verdeeld is over de werknemers in Nederland. Het komt relatief veel voor bij hoogopgeleiden en mannen in leidinggevende posities die ver van hun werk wonen. De vraag is dan ook of de gevonden relaties stand houden wanneer gecorrigeerd wordt voor verschillen in achtergrond. Deze paragraaf analyseert de relatie tussen thuis- en telewerk en ziekteverzuim enerzijds, en thuis- en telewerk en arbeidsduur van arbeidsgehandicapten anderzijds, met inachtneming van verschillen in achtergrond en omstandigheden tussen de respondenten. Het analytisch kader zoals uiteengezet in de tweede paragraaf dient als basis.

De data die we daarvoor gebruiken, zijn afkomstig uit het NEA-cohortonderzoek (Koppes et al., 2011b). Het NEA-cohortonderzoek loopt sinds 2007. De respondenten die aan de NEA 2007 hebben deelgenomen, zijn - voor het cohortonderzoek - in 2008 en 2009 opnieuw bevraagd, uitgaande van dezelfde vragenlijst. In 2007 deden 22.759 werknemers mee. Daarvan vulden in 2008 en 2009, 10.393 respectievelijk 7.909 werknemers opnieuw de vragenlijst in. Het voordeel van dit cohortonderzoek ten opzichte van de cross-sectionele NEA, waarbij alle variabelen op een moment gemeten worden, is dat het ons in staat stelt analyses te doen die rekening houden met veranderingen in de tijd op persoonsniveau. Met paneldata kan zodoende een causaal verband aannemelijk worden gemaakt. Individuele achtergrondkenmerken die wij relevant achten bij het analyseren van variaties in ziekteverzuim, zijn: geslacht, leeftijd, opleiding, aanwezigheid van thuiswonende kinderen, en het al dan niet hebben van een partner met een betaalde baan (en derhalve eigen inkomen). Op basis van inzichten uit eerder onderzoek (bijvoorbeeld Jehoel-Gijsbers, 2007, 2010) kan verwacht worden dat het ziekteverzuim hoger is bij vrouwen, ouderen en lager opgeleiden. Door de belasting die zorg voor kinderen met zich meebrengt, verwachten we tevens dat ziekteverzuim hoger ligt bij mensen met thuiswonende kinderen. Wat verwacht 
kan worden van het hebben van een partner met een betaalde baan, lijkt ambigu; wanneer de partner geen betaalde baan heeft, is het huishoudinkomen niet (deels) afgedekt door de inbreng van de partner en derhalve het risico op inkomstenverlies door baanverlies bij een hoog ziekteverzuim hoger. Hierdoor zullen zieke werknemers wellicht eerder doorwerken bij ziekte. Daartegenover staat dat wanneer beide partners werken, de kans op moeilijkheden bij de afstemming tussen werk en zorg groter is, zeker wanneer er kinderen zijn. Hierdoor stijgt wellicht de kans op ziekte en ziekteverzuim. Eenzelfde redeneerlijn kan gevolgd worden voor de respondenten zonder partner; het niet kunnen terugvallen op het inkomen van de partner maakt wellicht dat de werknemer eerder doorwerkt bij ziekte om het risico op baanverlies niet te laten stijgen. Daar staat tegenover dat werk en zorg terechtkomen op één persoon, waardoor de kans op ziekte en ziekteverzuim toe zou kunnen nemen. Relevant geachte baankenmerken zijn: sector, organisatiegrootte, en de mate waarin iemand leiding geeft. Zo verwachten we een hoger ziekteverzuim bij de overheid en bij grotere organisaties, en een lager verzuim bij leidinggevenden.

De analyse naar de relatie tussen ziekteverzuim en thuis- en telewerk is opgebouwd uit verschillende stappen. De resultaten worden weergegeven in tabel 2. Eerst schatten we een basismodel waarbij we rekening houden met een aantal individuele en baankenmerken (kolom 1). Vervolgens breiden we de analyse uit met intermediërende omstandigheden (kolom 2 - ervaren autonomie, afstemming arbeid en zorg, en relatie met leidinggevende en collega's) en prestatie-indicatoren (kolom 3 - baantevredenheid, prestaties en productiviteit en loopbaanperspectieven), zoals weergegeven in het analytisch kader. Door de resultaten van de verschillende stappen te tonen wordt inzicht gegeven in de (on)gevoeligheid van het effect van thuis- en telewerk op ziekteverzuim voor opname van andere verklarende factoren.

We kiezen ervoor Random Effects (RE)-modellen te schatten. Het voordeel van een RE-model is dat de individuele effecten over de jaren kunnen variëren en niet vaststaan, zoals bij Fixed Effects (FE)- modellen. ${ }^{3}$ Om te corrigeren voor de waarschijnlijk aanwezige overlap tussen thuis- en telewerk nemen we beide dummyvariabelen op in de analyses. Zodoende kan het zuivere effect van telewerk en van thuiswerk geschat worden. ${ }^{4}$ 
Leidt flexibilisering van werktijden en -plaats tot gezondheidsrisico's?

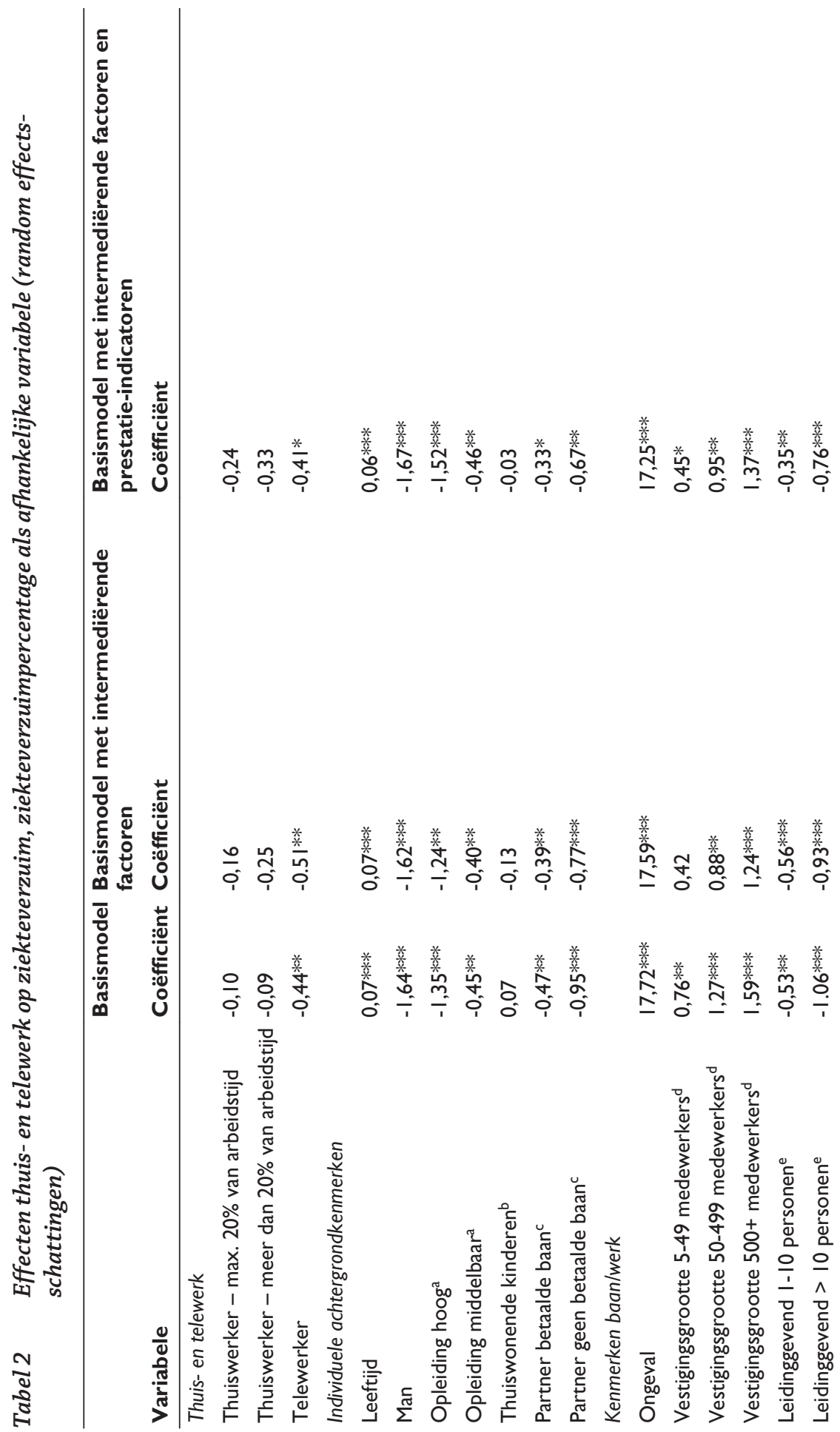




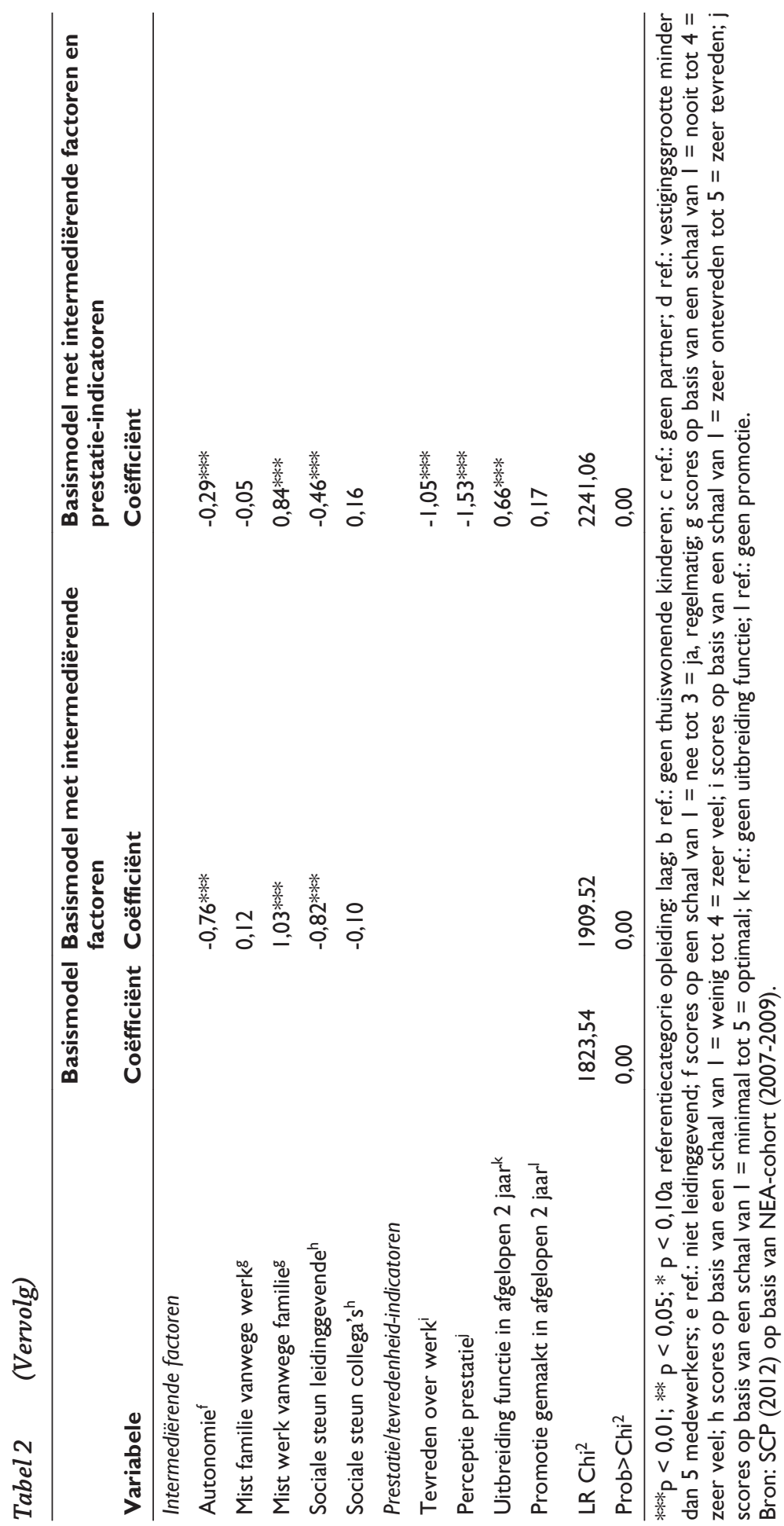


Telewerk blijkt ziekteverzuim te verminderen met een kleine half procentpunt. Het effect is - hoewel bij het meest uitgebreide model met een betrouwbaarheid van 90 procent - significant in alle drie de modellen. De uitbreidingen van het basismodel (met intermediërende factoren en prestatie-indicatoren) blijkt het effect van telewerk slechts in geringe mate te beïnvloeden.

Tegenover de bevinding dat telewerk ziekteverzuim reduceert, staat de constatering dat mensen die in mindere of meerdere mate thuiswerken - anders dan telewerk thuis -geen ander ziekteverzuim kennen dan mensen die dat niet doen. Het lagere ziekteverzuim bij thuiswerkers dat we zagen in de voorgaande paragraaf, zou zodoende veroorzaakt kunnen zijn door telewerken thuis. De aanwezigheid van een significant verschil in ziekteverzuim tussen telewerkers en niet-telewerkers, zoals we dat zagen in de vorige paragraaf, blijkt ook wanneer gecorrigeerd wordt voor verschillen in individuele en baankenmerken, stand te houden.

Om het effect van telewerken thuis te kunnen zien, hebben we een aanvullende schatting van het basismodel verricht. Omdat het effect van thuiswerk niet significant is, kunnen de coëfficiëntwaarden voor telewerk en thuiswerk niet zonder meer opgeteld worden om het effect van telewerken thuis te kunnen bepalen. Voor de aanvullende analyse zijn vijf nieuwe dummy-variabelen geconstrueerd: telewerker maar geen thuiswerker, telewerker en thuiswerkend voor maximaal 20 procent van de werktijd, telewerker en thuiswerkend voor meer dan 20 procent van de werktijd, thuiswerker voor maximaal 20 procent van de werktijd maar geen telewerker, thuiswerker voor meer dan 20 procent van de werktijd, maar geen telewerker. De referentiecategorie is geen thuis- of telewerker. De schattingsresultaten laten zien dat het ziekteverzuim reducerende effect alleen geldt voor werknemers die maximaal 20 procent van hun werktijd thuis- en telewerken. Voor de overige groepen is het gevonden effect weliswaar negatief, i.e. ziekteverzuim reducerend, maar niet significant. Telewerk en thuiswerken voor maximaal 20 procent van de werktijd verlaagt het ziekteverzuim met 0,59 procentpunt, zo laat deze analyse zien.

Andere factoren die ziekteverzuim verminderen, zijn: een hoge opleiding en het bekleden van een leidinggevende positie. Een mogelijke verklaring hiervoor is dat een hoge opleiding maakt dat iemand meer keuze heeft aan 'betere beroepen' of beroepen met meer regelmogelijkheden en minder zwaar werk. Beide dragen bij aan een betere gezondheid. Ook ligt het gemiddeld ziekteverzuim van mannen onder dat van vrouwen. Het hebben van een partner, al dan niet met een betaalde baan, doet eveneens het ziekteverzuim dalen. De wederzijdse zorgplicht voor partners zorgt er kennelijk voor dat men minder snel ziek wordt of zich bij ziekte minder snel ziek meldt. Factoren die ziekteverzuim doen stijgen, zijn: leeftijd en organisatiegrootte. Klaarblijkelijk aarzelen mensen die werken voor grotere organisaties, minder snel om zich ziek te melden. Dat gezondheidsproblematiek - en daarmee samenhangend ziekteverzuim - vaker voorkomt bij oudere mensen, is in lijn met eerder onderzoek (Klein Hesselink et al., 2012). Een andere ziekteverzuim bevorderende factor, die we voor de volledigheid noemen, is het meemaken van een arbeidsongeval. De aanwezigheid van kinderen in het huishouden blijkt het ziekteverzuimpercentage niet significant te beïnvloeden. Ook verschillen tus- 
Tabel 3a Vergelijking telewerkers en niet-telewerkers

\begin{tabular}{llll}
\hline Variabele & $\begin{array}{l}\text { Gemiddelde score }_{\text {telewerkers }}{ }^{\mathrm{a}} \\
\text { Autonomie }\end{array}$ & $\begin{array}{l}\text { Gemiddelde score } \\
\text { niet-telewerkers }\end{array}$ & F (sign.) \\
\hline Sociale steun leidinggevende & 2,74 & 2,53 & $865,64(0,00)$ \\
Sociale steun collega's & 3,28 & 2,84 & $78,96(0,00)$ \\
Mist familie vanwege werk & 1,82 & 3,26 & $5,15(0,23)$ \\
Mist werk vanwege familie & I,46 & 1,62 & $381,04(0,00)$ \\
\hline
\end{tabular}

a Scores op basis van een schaal van I = zeer weinig tot $5=$ zeer veel.

Bron: SCP (20I2) op basis van NEA-cohort (2007-2009)

sen beroepen of functies blijken qua ziekteverzuimpercentage niet significant te zijn. $^{5}$

Naast het basismodel hebben we twee modellen geschat waarin mediërende factoren en indicatoren voor prestaties en tevredenheid zijn meegenomen (analoog aan het analytisch kader). Naast deze twee hebben we ook een model geschat waarin de interactie-effecten tussen telewerk enerzijds en autonomie, afstemming arbeid en zorg, en relatie met leidinggevende en collega's anderzijds opgenomen waren. Geen van deze interactie-effecten bleek significant en de resultaten van dit model zijn niet opgenomen in tabel 2.

Wel kan gesteld worden dat thuis- of telewerkers meer autonomie ervaren bij het uitvoeren van hun functie dan niet-thuis- of telewerkers (zie tabel $3 \mathrm{a}$ en $3 \mathrm{~b}$ ). Bij thuis- of telewerkers verloopt de afstemming tussen werk en familie evenwel minder goed dan bij niet-thuis- of telewerkers. Vaker hebben zij het gevoel ofwel de familie tekort te doen vanwege werkverplichtingen ofwel het werk vanwege familieverantwoordelijkheden. De vervaging van strikte grenzen tussen werk en privé leidt kennelijk tot gevoelens van 'nooit meer klaar zijn met werk' en 'rolonduidelijkheid'. De relatie met de leidinggevende lijkt evenwel niet te lijden onder het werk op afstand. Thuis- of telewerkers ontvangen relatief veel sociale steun van hun leidinggevende. De sociale steun van collega's is voor telewerkers en niettelewerkers gelijk. Bij mensen die meer dan 20 procent van de werktijd thuiswerken, is daarentegen wel iets minder sprake van sociale steun van collega's dan bij degenen die niet of in geringe mate thuiswerken. De steun is het grootst voor de werknemers die af en toe (maximaal 20 procent van de werktijd) thuiswerken.

Wanneer autonomie, relaties met leidinggevende en collega's, en werk en zorgafstemming toegevoegd worden aan het basismodel, neemt de verzuim reducerende invloed van telewerk op ziekteverzuim iets toe. Tabel 2 toont verder dat meer autonomie in het werk en sociale steun van de leidinggevende significant bijdragen aan een lager ziekteverzuimpercentage. Sociale steun van collega's heeft daarentegen geen invloed. Personen die aangeven vaak het gevoel te hebben werk te missen dan wel te verwaarlozen door familieverantwoordelijkheden, hebben een hoger ziekteverzuimpercentage dan degenen die dat gevoel een enkele keer of niet hebben. Op basis hiervan is evenwel niet aan te geven of mensen vooral 
Tabel 3b Vergelijking thuiswerkers en niet-thuiswerkers

\begin{tabular}{|c|c|c|c|c|}
\hline Variabele & $\begin{array}{l}\text { Gemiddelde } \\
\text { score thuiswer- } \\
\text { kers max. } 20 \%^{\text {a }}\end{array}$ & $\begin{array}{l}\text { Gemiddelde } \\
\text { score thuis- } \\
\text { werkers }>\mathbf{2 0 \%}\end{array}$ & $\begin{array}{l}\text { Gemiddelde } \\
\text { score niet- } \\
\text { thuiswerkers }\end{array}$ & F (sign.) \\
\hline Autonomie & 2,65 & 2,61 & 2,53 & $223,12(0,00)$ \\
\hline $\begin{array}{l}\text { Sociale steun leidingge- } \\
\text { vende }\end{array}$ & 2,89 & 2,87 & 2,83 & $27,03(0,00)$ \\
\hline Sociale steun collega's & 3,28 & 3,22 & 3,26 & $\mid 4,87(0,00)$ \\
\hline $\begin{array}{l}\text { Mist familie vanwege } \\
\text { werk }\end{array}$ & 1,82 & $\mathrm{I}, 84$ & $\mathrm{I}, 58$ & $501,95(0,00)$ \\
\hline $\begin{array}{l}\text { Mist werk vanwege fami- } \\
\text { lie }\end{array}$ & $\mathrm{I}, 43$ & $\mathrm{I}, 47$ & $\mathrm{I}, 28$ & $398,4 \mid(0,00)$ \\
\hline
\end{tabular}

a Scores op basis van een schaal van I = zeer weinig tot $5=$ zeer veel.

Bron: SCP (20I2) op basis van NEA-cohort (2007-2009)

werk- of vooral familiegeoriënteerd zijn. Dat mensen het gevoel hebben hun werk te verwaarlozen of te missen, hoeft niet te betekenen dat werk voor hen ook op de eerste plaats komt. Wellicht zijn zij sterk familiegeoriënteerd, wat leidt tot een hoger ziekteverzuimpercentage en gemis aan werk(activiteiten). Factoren die verder een reducerend effect laten zien op ziekteverzuim, zijn de gepercipieerde eigen prestaties, de tevredenheid met het werk en de mate waarin de werkzaamheden de afgelopen jaren uitgebreid zijn. Naarmate mensen meer tevreden zijn over hun werk, hun prestaties als beter beoordelen en meer verantwoordelijkheden krijgen, daalt het ziekteverzuim. Bij deze laatste factoren moet evenwel opgemerkt worden - zoals ook aangegeven in het analytisch kader - dat de richting van de causaliteit niet eenduidig aan te geven is.

\section{Conclusies}

Werknemers in de flexibele schil blijken geconfronteerd te worden met grotere gezondheidsrisico's dan werknemers in vaste dienst. De vraag die in dit artikel centraal stond, was of hiervan ook sprake is bij werknemers die flexibel werken in termen van plaats en tijd: de thuis- en telewerkers. Thuis- en telewerk is het afgelopen decennium steeds populairder geworden. Intensivering van thuis- en telewerk wordt als oplossing van verschillende maatschappelijke problemen gezien. Zo wordt verwacht dat het de afstemming van arbeid en zorg verbetert, omdat bij plaats- en tijdonafhankelijk werk arbeidstijden gemakkelijker rond zorgverplichtingen gepland kunnen worden en beter ingespeeld kan worden op crises in de gezinssfeer. Ook biedt deze werkvorm mogelijkheden om de arbeidsproductiviteit te laten stijgen en ziekteverzuim te verminderen door vergroting van de autonomie van de werknemer en vermindering van (reis- en kantoor)stress. Maar daar staat tegenover dat thuis- en telewerk mogelijk leidt tot gevoelens van werkvervreemding of van het niet meer los kunnen laten van het werk en nooit meer klaar zijn met werk. Ook zou het de relatie met collega's of leidinggevenden onder 
druk kunnen zetten. Deze gevoelens zouden kunnen leiden tot gezondheidsproblemen en een verhoogd ziekteverzuim.

De analyses laten zien dat flexibilisering van werktijden en -plaats juist vermindering van gezondheidsrisico's betekent. Telewerkers (inclusief de combinatie met thuiswerk) blijken een lager ziekteverzuimpercentage te kennen dan vergelijkbare werknemers die niet telewerken. Daarbij gaat het om een ziekteverzuimreductie van 0,4 tot 0,5 procentpunt. Zij ervaren - in tegenstelling tot werknemers in de flexibele schil - ook meer autonomie in hun werk en hebben ten opzichte van niet-telewerkers een betere relatie met hun collega's en leidinggevenden. Terwijl we deze gunstige effecten ook vonden voor thuiswerkers, bleek thuiswerk (exclusief telewerk) niet te leiden tot minder ziekteverzuim. De kansen die tijd- en plaatsonafhankelijk werken biedt om gezondheidsrisico's te verminderen, hebben evenwel ook een keerzijde. Thuis- of telewerkers hebben verhoudingsgewijs vaak last van afstemmingsproblemen; zij hebben vaker het gevoel ofwel de familie tekort te doen vanwege werkverplichtingen ofwel het werk vanwege familieverantwoordelijkheden.

\section{Noten}

1 De analyses in dit artikel zijn een verkorte weergave van het hoofdstuk 'De impact van thuis- en telewerk op ziekteverzuim en arbeidsdeelname arbeidsgehandicapten' uit de SCP-publicatie Belemmerd aan het werk (2012, pp. 105-123).

2 Bivariate toetsen met post-hoc tests laten zien dat het verschil in ziekteverzuim tussen niet-thuiswerkers en mensen die meer dan 20 procent thuiswerken, niet significant is.

3 Hoge rho-waarden van de FE-schattingen wijzen ook in de richting van RE-modellering.

4 De kruistabellen van de twee dummy's laten zien dat voor elk van de combinaties thuis- en telewerk voldoende waarnemingen aanwezig zijn om de separate effecten te kunnen schatten.

5 We hebben analyses gedaan met daarin opgenomen negen verschillende functies. Los van de leidinggevende beroepen bleek geen van de functies invloed te hebben op ziekteverzuim. Vanuit het streven de modellen niet overbodig groot te laten zijn, hebben we deze variabele uiteindelijk weggelaten. In plaats van de variabele functie/sector hebben we een variabele opgenomen die aangeeft in welke mate sprake is van leidinggeven.

\section{Literatuur}

Bailey, D.E. \& Kurland, N.B. (2002). A review of telework research: Findings, new directions and lessons for the study of modern work. Journal of Organizational Behavior, 23(4), 383-400.

Baltes, B.B., Briggs, T.E., Huff, J.W., Wright J.A. \& Neuman, G.A. (1999). Flexible and compressed workweek schedules: A meta-analysis of their effects on work-related criteria. Journal of Applied Psychology, 84(4), 496-513. 
Baruch, Y. (2001). The status of research on teleworking and an agenda for future research. International Journal of Management Reviews, 3(2), 113-129.

Beer, P. de (2011). Nederland presteert uitstekend. Socialisme en Democratie, 68(9-10), 85-95.

Duxbury, L.E., Higgins, C.A. \& Neufeld, D. (1998). Telework and the balance between work and family: Is telework part of the problem or part of the solution? In M. Igbaria \& M. Tan (eds.), The virtual workplace (pp. 218-255). Hershey: Idea Group Publishing.

Echtelt, P. van (2010). Een baanloos bestaan. De betekenis van werk voor werklozen, arbeidsongeschikten en werkenden. Den Haag: SCP.

Gaalen, R. van, Goudswaard, A., Sanders, J. \& Smits, W. (2013). Dynamiek op de Nederlandse arbeidsmarkt, de focus op flexibilisering. Centraal Bureau voor de Statistiek en TNO. Den Haag: CBS.

Gajendran, R. \& Harrison, D. (2007).The good, the bad and the unknown about telecommuting: Meta-analysis of psychological mediators and individual consequences. Journal of Applied Psychology, 92(6), 1524-1541.

Hooftman, W., Klein Hesselink, J., Genabeek, J. van, Wiezer, N. \& Willems, D. (2011). Arbobalans 2010. Delft: TNO.

Igbaria, M. \& Guimaraes, T. (1999). Exploring differences in employee turnover intentions and its determinants among telecommuters. Journal of Management Information Systems, 6(1), 147-164.

Jehoel-Gijsbers, G. (2007). Beter aan het werk. Trendrapportage ziekteverzuim, arbeidsongeschiktheid en werkhervatting. Den Haag: SCP.

Jehoel-Gijsbers, G. (2010). Beperkt aan het werk. Trendrapportage ziekteverzuim, arbeidsongeschiktheid en werkhervatting. Den Haag: SCP.

Klein Hesselink, J., Houtman, I. \& Bossche, S. van den (2012). Trends in ziekteverzuim. In M.C. Versantvoort \& P. van Echtelt (red.), Belemmerd aan het werk, trendrapportage ziekteverzuim, arbeidsongeschiktheid en arbeidsdeelname personen met gezondheidsbeperkingen. Den Haag: SCP.

Konradt, U., Hertel, G. \& Schmook, R. (2003). Quality of management by objectives, taskrelated stressors, and non-task-related stressors as predictors of stress and job satisfaction among teleworkers. European Journal of Work and Organizational Psychology, 12(1), 61-79.

Koppes, L.L.J., Vroome, E.M.M. de, Mol, M.E.M. de, Janssen, B.J.M. \& Bossche, S.N.J. van den (2011a). Nationale enquête arbeidsomstandigheden 2010: methodologie en globale resultaten. Hoofddorp: TNO.

Koppes, L.L.J., Vroome, E.M.M. de \& Bossche, S.N.J. van den (2011b). NEA cohortonderzoek 2007-2009; methoden en eerste resultaten. Hoofddorp: TNO.

Mann, S. \& Holdsworth, L. (2003). The psychological impact of teleworking: Stress, emotions and health. New Technology, Work and Employment, 19, 196-211.

McClosky, D.W. \& Igbaria, M. (2003). Does 'out of sight' mean 'out of mind'? An empirical investigation of the career advancement prospects of telecommuters. Information Resources Management Journal, 16(2), 19-35.

Montreuil, S. \& Lippel, K. (2003). Telework and occupational health: A Quebec empirical study and regulatory implications. Safety Science, 41(4), 339-358.

Raghuram, S. \& Wiesenfeld, B. (2004). Work-nonwork conflict and job stress among virtual workers. Human Resource Management, 43, 259-277.

SCP (2012). Belemmerd aan het werk. Trendrapportage ziekteverzuim, arbeidsongeschiktheid en arbeidsdeelname van personen met gezondheidsbeperkingen. Den Haag: SCP.

Smulders, P., Kraan, K. \& Pot, F. (2011). Telewerkers vormen een elite. Economisch Statistische Berichten, 96, 493-495. 
Spector, P.E. (1986). Perceived control by employees: A meta analysis of studies concerning autonomy and participation at work. Human Relations, 39(11), 1005-1016.

Standen, P., Daniels, K. \& Lamond, D. (1999). The home as a workplace: Work-family interaction and psychological well-being in telework. Journal of Occupational Health Psychology, 4(4), 368-381. 